\title{
EMOTIONAL INTELLIGENCE AND WORK LIFE BALANCE OF WOMEN IT PROFESSIONALS IN BANGALORE
}

\author{
*Prof. T. RAVIKUMAR
}

\section{ABSTRACT}

Emotional intelligence (EI) is the ability to monitor one's own and other people's emotions, to discriminate between different emotions and label them appropriately, and to use emotional information to guide thinking and behavior. Work-life balance is a concept including proper prioritizing between "work" (career and ambition) and "lifestyle" (health, pleasure, leisure, family and spiritual development/meditation). The ways in which corporations especially Information Technology companies have modeled the "ideal worker" does not compliment the family lifestyle, nor does it accommodate it. Long hours and near complete devotion to the profession makes it difficult for working mothers to participate in getting ahead in the workplace. Should a woman seek a position of power within an organization, she must consider the toll on other facets of her life, including hobbies, personal relationships and families. Work life balance should be maintained for an efficient and effective life. Here, a question arises what is the role of emotional intelligence in balancing work-life of women employees especially IT professionals. This study has made an attempt to answer the above question. The study is designed to analyze role of emotional intelligence on work life balance of women IT. professional in Bangalore city. The study employed survey method of data collection using structured questionnaire. According to Krejcie and Morgan (1970), the minimum number of sample size was determined as 383 employees. The study has employed Regression analysis to find out role of emotional intelligence in work life balance of women IT professionals.

Keywords: Emotional intelligence, Work life balance, Women IT professionals

\section{INTRODUCTION}

Finding a suitable balance between work and daily living is a challenge that all workers face. Families are particularly affected. Some couples would like to have (more) children, but do not see how they could afford to stop working. Other parents are happy with the number of children in their family, but would like to work more. This is a challenge to governments because if parents cannot achieve their desired work/life balance, not only is their welfare lowered but so is development in the country.

The distribution of tasks within the family is still influenced by gender roles: men are more likely to spend more hours in paid work, while women spend longer hours in unpaid domestic work. While on average men spend 141 minutes per day doing unpaid work, women spend 273

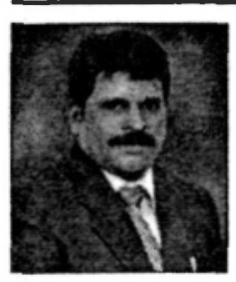

*Prof. T. RAVIKUMAR

Assistant Professor

Dept. Of Management Studies

Christ University, Bangalore - 29 
minutes per day cooking, cleaning or caring. This average difference, approximately 2.3 hours per day, conceals many disparities among countries. For instance Turkish and Mexican women spend approximately 4.3 hours more than men working on domestic chores.

An important aspect of work-life balance is the amount of time a person spends at work. Evidence suggests that long work hours may impair personal health, jeopardize safety and increase stress. Furthermore, the more people work, the less time they have to spend on other activities, such as personal care or leisure. The amount and quality of leisure time is important for people's overall well-being, and can bring additional physical and mental health benefits.

Emotional Intelligence is a set of qualities and competencies that captures a broad collection of individual skills and dispositions, usually referred to as soft skills or inter and intra-personal skills, that are outside the traditional areas of specific knowledge, general intelligence and technical or professional skills. Emotions are an intrinsic part of our biological makeup and every morning they march into the office with us and influence our behaviour.

Emotional intelligence consists of five factors: Knowing one's emotions, managing emotions, motivating one, recognizing emotions in others and handling relationships. Researchers today are interested in finding the effects of emotional intelligence on employees and thereby, organizations, and analyzing the various other facets of EQ. Emotional intelligence improves individual and organizational performance. It plays a significant role in the kind of work an employee produces and the relationship he or she enjoys in the organization.

\section{NEED FOR THE STUDY}

In the modern competitive IT world, the concept of emotional intelligence plays a very crucial role. Research suggests that traditional intelligence i.e. IQ contributes only $20 \%$ to an individuals' success where as emotional intelligence i.e. EQ contributes $80 \%$ to an individuals' success. Women have a number of roles that they play throughout life. Work-life conflict occurs when time and energy demands imposed by the diverse roles cannot be efficiently met, as participation in one role is made increasingly difficult by participation in another. Due to the Indian social structure, prejudices and myths women employees used to face barriers in work environment. It is essential to test empirically that whether emotional intelligence has positive role on work life balance of women IT professionals or not. Therefore, the study has made attempt in that direction.

\section{OBJECTIVES OF THE STUDY}

The main objectives of the study are given below;

1. To examine emotional intelligence of women IT professionals in Bangalore city in relation to demographic, economic and work related characteristics

2. To study about role of emotional intelligence on work life balance of women IT professionals in Bangalore city

\section{RESEARCH METHODOLOGY}

This study is based on primary data. The quality of data is invariably tied to the method and technique used for data collection. Hence, survey method through structured questionnaire is adopted to collect primary data for this study as it is found suitable for this research. Sample population of the study is women IT professionals in Bangalore city. Sample size is 383 which is determined on the basis of Krejcie and Morgan 
study. The study used snow ball sampling for this research. After the distribution of 400 questionnaires, 383 filled questionnaires were gathered from women IT professionals.

In order to collect the necessary data, a well structured questionnaire was used. The questionnaire consists of two sections. First section includes 10 questions about demographic information of respondents.
Second section contains 16 statements of Likert's five point scale representing mental health, physical health, working hours, welfare measures, conveyance etc., to measure work life balance of women IT professionals. Further, third section contains another 24 statements of Likert's five point scale representing self awareness, social awareness, self management and social skills to measure emotional intelligence of sample respondents.

\section{ANALYSIS AND INTERPRETATION}

IV.1. Analysis Of Demographic, Economic And Work Related Characteristics Of The Respondents

Table - 1 : Demographic, Economic And Work Related Characteristics

Of The Respondents

\begin{tabular}{|c|c|c|c|}
\hline NO & PARTICULARS & $\begin{array}{c}\text { NO. OF } \\
\text { RESPONDENTS }\end{array}$ & PERCENTAGES \\
\hline \multirow[t]{6}{*}{1} & \multicolumn{3}{|c|}{ MARITAL STATUS } \\
\hline & Single & 184 & 48.0 \\
\hline & Married & 159 & 41.5 \\
\hline & Divorcee & 032 & 8.4 \\
\hline & Widower & $\overline{008}$ & 2.1 \\
\hline & Total & 383 & 100.00 \\
\hline \multirow[t]{4}{*}{2} & \multicolumn{3}{|c|}{ NUMBER OF CHILDREN } \\
\hline & Only one & 171 & 92.4 \\
\hline & Two & 014 & 07.6 \\
\hline & Total & 185 & 100.0 \\
\hline \multirow{6}{*}{3} & \multicolumn{3}{|c|}{ AGE } \\
\hline & Up to 20 years & 165 & 43.1 \\
\hline & 21 to 35 years & 100 & 26.1 \\
\hline & 36 to 50 years & 087 & 22.7 \\
\hline & More than 50 years & 031 & 08.1 \\
\hline & Total & 383 & 100.0 \\
\hline
\end{tabular}




\begin{tabular}{|c|c|c|c|}
\hline 4 & \multicolumn{3}{|c|}{ EDUCATION } \\
\hline & Under Graduate & 184 & 48.0 \\
\hline & Post Graduate & 199 & 52.0 \\
\hline & Total & 383 & 100.0 \\
\hline 5 & \multicolumn{3}{|c|}{ GROSS ANNUAL INCOME (Rs) } \\
\hline & Up to 100000 & 039 & 10.2 \\
\hline & 100001 to 300000 & 162 & 42.3 \\
\hline & 300001 to 500000 & 158 & 41.3 \\
\hline & More than 500000 & 024 & 06.3 \\
\hline & Total & 383 & 100.0 \\
\hline \multirow[t]{6}{*}{6} & \multicolumn{3}{|c|}{ NUMBER OF DEPENDENTS } \\
\hline & Up to 2 members & 146 & 38.1 \\
\hline & 3 to 4 members & 095 & 24.8 \\
\hline & 5 to 6 members & 091 & 23.8 \\
\hline & More than 6 members & 051 & 13.3 \\
\hline & Total & 383 & 100.0 \\
\hline \multirow[t]{6}{*}{7} & \multicolumn{3}{|c|}{ TOTAL EXPERIENCE } \\
\hline & Up to 3 years & 135 & 35.2 \\
\hline & 3 years 1 day to 10 years & 117 & 30.5 \\
\hline & 10 years 1 day to 20 years & 078 & 20.4 \\
\hline & More than 20 years & 053 & 13.8 \\
\hline & Total & 383 & 100.0 \\
\hline \multirow[t]{6}{*}{8} & \multicolumn{3}{|c|}{ EXPERIENCE IN IT SECTOR } \\
\hline & Up to 3 years & 135 & 35.2 \\
\hline & 3 years 1 day to 10 years & 109 & 28.5 \\
\hline & 10 years 1 day to 20 years & 087 & 22.7 \\
\hline & More than 20 years & 052 & 13.6 \\
\hline & Total & 383 & 100.0 \\
\hline
\end{tabular}


The most important features of demographic, economic and work related characteristics of women IT professionals;

1. $48 \%$ of the respondents are single, $41.5 \%$ of the respondents are married, $8.4 \%$ of the respondents are divorcee and $2.1 \%$ of the respondents are widower.

2. Out of married women. $92.4 \%$ of the respondents (171 respondents) have only one child and $7.6 \%$ of the respondents (14 respondents) have two children.

3. Interestingly, most of the respondents $(43.1 \%)$ are less than 20 years old, $26.1 \%$ of the respondents belong to the age group of 21 years to 35 years, $22.7 \%$ of the respondents belong to the age group of 36 years to 50 years and only $8.1 \%$ of the respondents belong to the age group of more than 50 years.

4. $52 \%$ of the respondents have completed post graduation and $48 \%$ of the respondents have completed under graduation.

5. $83.6 \%$ of the respondents have annual income of Rs 1.00 .001 to $5.00,000$ and $6.3 \%$ of the respondents have annual income of more than Rs 5,00,000.

6. $38.1 \%$ of the respondents have 2 or less than 2 dependents, $48.6 \%$ of the respondents have 3 to 6 dependents and $13.3 \%$ of the respondents have more than 6 dependents.

7. $35.2 \%$ of the respondents have total experience of 3 or less than 3 years, $30.5 \%$ of the respondents have total experience of 3 years 1 day to 10 years. $20.4 \%$ of the respondents have total experience of 10 years 1 day to 20 years and $13.8 \%$ of the respondents have more than 20 years experience.
8. $35.2 \%$ of the respondents have total experience of 3 or less than 3 years IT sector, $28.5 \%$ of the respondents have total experience of 3 years 1 day to 10 years in IT sector. $22.7 \%$ of the respondents have total experience of 10 years 1 day to 20 years in IT and $13.6 \%$ of the respondents have more than 20 years experience in IT.

\section{IV.2. ANALYSIS OF EMOTIONAL INTELLIGENCE OF WOMEN IT PROFESSIONALS}

Emotion was not considered part of the intelligence domain for two millennia, as evidenced by historical accounts of philosophical debates that occurred among early Roman and Greek philosophers who thought emotion was too unpredictable to be part of rational thought.

Scholarly discussions treated emotions with a negative connotation early to mid 1900's. Emotions were thought of as overcoming and ruling individuals. Emotions were to be controlled by the individual or he or she would succumb to their influences.

Emotions were later thought of as positive aspects of humans helping to prioritize tasks, organize, focus, and motivate one. It was also realized that emotions are holistic in nature as they involve the whole human mind and body. Research also suggested that emotions emerged in the human species through the evolutionary process "to provide new types of motivation and new action tendencies as well as a greater variety of behaviors to cope with the environment and life's demands". Therefore, this study makes an attempt to analyze emotional intelligence of women IT professionals. 
Table -2

Marital Status And Emotional Intelligence Of Women It Professionals

\begin{tabular}{|l|c|c|c|c|}
\hline \multicolumn{1}{|c|}{ Marital status } & Mean Value & F value & P Value & Result \\
\cline { 1 - 2 } Single & 2.3084 & & & \\
\cline { 1 - 2 } Married & 2.3237 & \multirow{2}{*}{.664} & $.575^{*}$ & $\begin{array}{c}\text { Not } \\
\text { Significant }\end{array}$ \\
\cline { 1 - 2 } Divorcee & 2.5015 & & & \\
\hline
\end{tabular}

Source: Primary data,

*At $1 \%$ level of significance ${ }^{* *}$ At $5 \%$ level of significance

The one way ANOVA Table -2 displays that there is no significant difference between marital status and emotional intelligence level of women IT professionals. From this, it can be understood that emotional intelligence level of women IT professionals do not differ on the basis of their marital status.

Table -3

Number Of Children And Emotional Intelligence Of Women It Professionals

\begin{tabular}{|l|c|c|c|c|}
\hline \multicolumn{1}{|c|}{ Number of children } & Mean Value & F value & P Value & Result \\
\cline { 1 - 2 } Only one & 2.3738 & \multirow{2}{*}{3.273} & $.072^{* *}$ & Not significant \\
\hline Two & 1.9661 & & & \\
\hline
\end{tabular}

Source: Primary data,

*At $1 \%$ level of significance ${ }^{* *}$ At $5 \%$ level of significance

The one way ANOVA Table - 3 displays that there is no significant difference between number of children and emotional intelligence level of women IT professionals. From this, it can be understood that emotional intelligence level of women IT professionals do not differ on the basis of their number of children. 
Table -4

Age And Emotional Intelligence Of Women It Professionals

\begin{tabular}{|l|c|c|c|c|}
\hline \multicolumn{1}{|c|}{ Age } & Mean Value & F value & P Value & Result \\
\cline { 1 - 2 } Up to 20 years & 2.4555 & & & \\
\cline { 1 - 2 } 21 to 35 years & 2.2216 & \multirow{2}{*}{4.969} & $.002^{* *}$ & \multirow{2}{*}{ Significant } \\
\cline { 1 - 2 } 36 to 50 years & 2.1362 & & & \\
\hline More than 50 years & 2.4839 & & & \\
\hline
\end{tabular}

Source: Primary data,

*At $1 \%$ level of significance **At $5 \%$ level of significance

The One way ANOVA Table - 4 shows that there is a significant difference between age and emotional intelligence of women IT professionals. From this, it can be understood that emotional intelligence levels of women IT professionals differ on the basis of age of women IT professionals. Mean scores of one way ANOVA indicate that women IT professionals aged more than 50 years have high level of emotional intelligence (2.4839) followed by women IT professionals aged 20 years or less than 20 years (2.4555), women IT professionals aged 21 years to 35 years (2.2216) and women IT professionals aged 36 years to 50 years $(2.1362)$.

Table -5

Education And Emotional Intelligence Of Women It Professionals

\begin{tabular}{|c|c|c|c|c|}
\hline Education & Mean Value & F value & P Value & Result \\
\hline Under Graduate & 2.3605 & & & \\
\hline Post Graduate & 2.3109 & .382 & $.537^{* *}$ & $\begin{array}{c}\text { Not } \\
\text { Significant }\end{array}$ \\
\hline
\end{tabular}

Source: Primary data, ${ }^{*}$ At $1 \%$ level of significance $\quad{ }^{* *}$ At $5 \%$ level of significance

The one way ANOVA Table -5 displays that there is no significant difference between education and emotional intelligence level of women IT professionals. From this, it can be understood that emotional intelligence level of women IT professionals do not differ on the basis of their education. 
Table - 6

Gross Annual Income And Emotional Intelligence Of Women It Professionals

\begin{tabular}{|l|c|c|c|c|}
\hline \multicolumn{1}{|c|}{ Gross annual income } & Mean Value & F value & P Value & Result \\
\hline Up to 100000 & 2.5055 & & & \\
\cline { 1 - 2 } 100001 to 300000 & 2.3465 & \multirow{3}{*}{3.843} & \multirow{2}{*}{$.010^{* *}$} & \\
\cline { 1 - 2 } 300001 to 500000 & 2.3546 & & & Significant \\
\hline More than 500000 & 1.8465 & & & \\
\hline
\end{tabular}

Source: Primary data,

*At $1 \%$ level of significance **At $5 \%$ level of significance

The One way ANOVA Table - 6 shows that there is a significant difference between gross annual income and emotional intelligence of women IT professionals. Therefore, it can be observed that emotional intelligence of women IT professionals differ on the basis of gross annual income of women IT professionals. Mean scores of one way ANOVA indicate that women IT professionals having gross annual income of Rs $1,00,000$ or less than Rs $1,00,000$ (2.5055) possess high level of emotional intelligence (2.2850) followed by women IT professionals having gross annual income of Rs 3,00,001 to $5,00,000(2.3546)$, women IT professionals having gross annual income of Rs $1,00,001$ to Rs $3,00,000$ (2.3465) and women IT professionals having gross annual income of more than Rs 5,00,000 (1.8465).

The one way ANOVA Table - 7 displays that there is no significant difference between number of dependents and emotional intelligence level of women IT professionals. From this, it can be understood that emotional intelligence level of women IT professionals do not differ on the basis of their number of dependents.

\section{Table -7}

Number Of Dependents And Emotional Intelligence Of Women It Professionals

\begin{tabular}{|l|c|c|c|c|}
\hline \multicolumn{1}{|c|}{ Number of dependents } & Mean Value & F value & P Value & Result \\
\cline { 1 - 2 } Up to 2 members & 2.3587 & & & \\
\cline { 1 - 2 } to 4 members & 2.3532 & .231 & $.875^{* *}$ & $\begin{array}{c}\text { Not } \\
\text { Significant }\end{array}$ \\
\cline { 1 - 3 } More than 6 members & 2.3190 & & & \\
\hline
\end{tabular}

Source: Primary data,

*At $1 \%$ level of significance **At $5 \%$ level of significance 
The One way ANOVA Table - 8 shows that there is a significant difference between total experience and emotional intelligence of women IT professionals. So, emotional intelligence levels of women IT professionals differ on the basis of total experience of women IT professionals. Mean scores of one way ANOVA indicate that women IT professionals having total experience of more than 20 years possess high level of emotional intelligence (3.3900) followed by women IT professionals having total experience of 10 years 1 day to 20 years (2.8227), women IT professionals having total experience of 3 years 1 day to 10 years (2.2594) and women IT professionals having total experience of 3 years or less than 3 years (1.7036). It should be noted that when total experience of women IT professionals increases, then, their work life balance level also increases.

Table - 8

Total Experience And Emotional Intelligence Of Women It Professionals

\begin{tabular}{|l|c|c|c|c|}
\hline \multicolumn{1}{|c|}{ Total experience } & Mean Value & F value & P Value & Result \\
\cline { 1 - 2 } Up to 3 years & 1.7036 & & & \\
\cline { 1 - 2 } 3 years 1 day to 10 years & 2.2594 & \multirow{2}{*}{161.709} & \multirow{2}{*}{$.000^{* *}$} & \\
\cline { 1 - 2 } 10 years 1 day to 20 years & 2.8227 & & & Significant \\
\cline { 1 - 2 } More than 20 years & 3.3900 & & & \\
\hline
\end{tabular}

Source: Primary data,

*At $1 \%$ level of significance **At $5 \%$ level of significance

Table - 9

Total Experience In It Sector And Emotional Intelligence Of Women It Professionals

\begin{tabular}{|l|c|c|c|c|}
\hline \multicolumn{1}{|c|}{ Total experience } & Mean Value & F value & P Value & Result \\
\cline { 1 - 2 } Up to 3 years & 1.7004 & & & \\
\cline { 1 - 2 } 3 years 1 day to 10 years & 2.2339 & \multirow{2}{*}{169.467} & $.000^{* *}$ & \\
\cline { 1 - 2 } 10 years 1 day to 20 years & 2.8011 & & & Significant \\
\cline { 1 - 2 } More than 20 years & 3.4123 & & & \\
\hline
\end{tabular}

Source: Primary data,

*At $1 \%$ level of significance **At $5 \%$ level of significance 
The One way ANOVA Table - 9 shows that there is a significant difference between experience in IT sector and emotional intelligence of women IT professionals. So, emotional intelligence levels of women IT professionals differ on the basis of experience in IT sector of women IT professionals. Mean scores of one way ANOVA indicate that women IT professionals having experience in IT sector of more than 20 years possess high level of emotional intelligence (3.4123) followed by women IT professionals having experience in IT sector of 10 years 1 day to 20 years $(2.8011)$, women IT professionals having experience in IT sector of 3 years 1 day to 10 years (2.2339) and women IT professionals having experience in IT sector of 3 years or less than 3 years (1.7004). It should be noted that when experience in IT sector of women IT professionals increases, then, their work life balance level also increases.

Differences in emotional intelligence perceptions of the respondents on the basis of demographic, economic and work related variables are analyzed and discussed in tables -2 to 9 using one way ANOVA(F test). Based on such analysis, comprehensive conclusions can be drawn on emotional intelligence perceptions of sample respondents which are as follows:

- The study results exhibit that women IT professional, who may be either married or unmarried, either completed graduation or post graduation, aged more than 50 years irrespective of number of dependents with gross annual income of Rs $1,00,000$ or less than Rs 1,00,000 having more than 20 years of total experience and more than 20 years experience in IT sector has higher level of emotional intelligence perception.
On the other hand, the study shows that women IT professional, who may be either married or unmarried, either completed graduation or post graduation, aged 36 years to 50 years irrespective of number of dependents with gross annual income of more than Rs 5,00,000 having up to 3 years of total experience and up to 3 years experience in IT sector has lower level of emotional intelligence perception.

\section{IV.3. A N A L Y S I S O F ROLE O F EMOTIONAL INTELLIGENCE ON WORK LIFE BALANCE OF WOMEN IT PROFESSIONALS}

\section{Hypothesis}

$\mathbf{H}_{\mathbf{0}}$ : There is no significant impact of emotional intelligence on work life balance of wo men IT professionals

In this part of the analysis, work life balance and independent variable are entered in to regression analysis. The independent variable is emotional intelligence and the dependent variable is work life balance of women IT professionals.

The Table - 10 shows the model summary for the R, R2, adjusted R2 and standard error of the estimate. The $R 2$ value indicates the percent of variance in the criterion (dependent variable) that is accounted for by the linear combination of predictor (independent) variables. Model 1 has R2 value of .642 which indicates the variance accounted for by the linear combination of awareness about financial inclusion, factors causing financial exclusion and respondents' expectation gap towards financial services and products. 
Table -10

Model Summary

\begin{tabular}{|c|c|c|c|c|}
\hline Model & $\mathrm{R}$ & $\mathrm{R}^{2}$ & Adjusted $\mathrm{R}^{2}$ & $\begin{array}{c}\text { Std. error of the } \\
\text { estimate }\end{array}$ \\
\hline 1 & $.801^{\mathrm{a}}$ & .642 & .641 & .49514 \\
\hline
\end{tabular}

a. Predictors: (Constant) Emotional intelligence

Table - 11

\begin{tabular}{|c|l|c|c|c|c|c|}
\hline \multicolumn{2}{|c|}{ ANOVA $^{\circ}$} \\
\hline \multirow{2}{*2}{ MODEL } & $\begin{array}{c}\text { Sum of } \\
\text { squares }\end{array}$ & $\mathrm{df}$ & $\begin{array}{c}\text { Mean } \\
\text { square }\end{array}$ & F & Significance \\
\hline \multirow{3}{*}{1} & Regression & 167.406 & 1 & 167.406 & & \\
\cline { 2 - 5 } & Residual & 93.406 & 381 & .245 & 682.846 & $.000^{\mathrm{b}}$ \\
\cline { 2 - 5 } & Total & 260.812 & 382 & & & \\
\hline
\end{tabular}

a. Predictors: (Constant) Emotional intelligence

b. Dependent variable: Work life balance

Table -12

\begin{tabular}{|c|c|c|c|c|c|c|}
\hline \multicolumn{7}{|c|}{ CO-EFFICIENTS $^{\mathrm{a}}$} \\
\hline & \multirow{2}{*}{ MODEL } & \multicolumn{2}{|c|}{$\begin{array}{c}\text { Unstandardized } \\
\text { coefficients }\end{array}$} & \multirow{2}{*}{$\begin{array}{c}\text { Standardized } \\
\text { coefficients } \\
\text { Beta }\end{array}$} & \multirow[t]{2}{*}{$\mathrm{T}$} & \multirow[t]{2}{*}{ Sig. } \\
\hline & & $\mathrm{B}$ & Std. error & & & \\
\hline \multirow[b]{2}{*}{1} & (Constant) & .334 & .080 & & 4.201 & .000 \\
\hline & $\begin{array}{l}\text { Emotional } \\
\text { intelligence }\end{array}$ & .844 & .032 & .801 & 26.131 & .000 \\
\hline
\end{tabular}

a. Dependent variable: Work life balance 
The Table - 12 shows that selected independent variable namely emotional intelligence has significant impact on work life balance of women IT professionals. The one way ANOVA ( $F$ test) in the table - 11 for model -1 is also statistically significant. Therefore, null hypothesis is rejected and it can be concluded that there is a significant impact of emotional intelligence on work life balance of women IT professionals in Bangalore city to the extent of $64.2 \%$.

\section{CONCLUSION}

The aim of the present study is to investigate role of emotional intelligence on work life balance of women IT professionals in Bangalore. Further, the study intends to analyze emotional intelligence of women IT professionals in relation to demographic, economic and work related variables. The study has found that women IT professional, who may be either married or unmarried, either completed graduation or post graduation, aged more than 50 years irrespective of number of dependents with gross annual income of Rs $1,00,000$ or less than Rs $1,00,000$ having more than 20 years of total experience and more than 20 years experience in IT sector has higher level of emotional intelligence perception. On the other hand, the study shows that women IT professional. who may be either married or unmarried, either completed graduation or post graduation, aged 36 years to 50 years irrespective of number of dependents with gross annual income of more than Rs 5,00,000 having up to 3 years of total experience and up to 3 years experience in IT sector has lower level of emotional intelligence perception. Further, this study has also found that there is a significant impact of emotional intelligence on work life balance of women IT professionals in Bangalore city.

\section{REFERENCES}

- Antonakis, J. (2003). Why "emotional intelligence" does not predict leadership effectiveness: A comment on the Prati, Douglas, Ferris, Ammeter, and Buckley (2003). The International Journal of Organizational Analysis, 11, 355-364.

- Atwater, L.E., \& Yammarino, F.J. (1992). Does self-other agreement on leadership perceptions moderate the validity of leadership and performance predictions? Personnel Psychology, 45, 141-164.

- Bachmann, K. (2000). Work - life Balance. Are Employers Listening? Conference Board of Canada.

- Barling, J., Slater, F., \& Kelloway, E. K. (2000). Transformational leadership and emotional intelligence: An exploratory study. Leadership \& Organization Development Journal, 21, 157-161.

- Bar-On, R. (1997). The Bar-On Emotional Quotient Inventory (EQ-I): A test of emotional intelligence. Toronto, Canada: Multi-Health Systems.

- Bhattacharya, M, S and Sengupta, N (2007), Emotional Intelligence Myth or Reality, Anurag Jain for Excel Books

- Bhargava, S\& Baral, $R$ (2009). Work - life Balance Practices in India. Working Paper; IIT Bombay.

- Blau,P.1964. Exchange and Power in Social Life. New York: Wiley

- Burke,M.J \& Collison, J. (2004). US Job Recovery and Retention Poll Findings for Human Resource Management.

- Boyatzis, R. E. (1999). From a presentation to the Linkage Conference on Emotional Intelligence, Chicago, IL, September 27. 1999. 
- Brown, F. W., Bryant, S. E., \& Reilly, M. D. (2005). Does emotional intelligence-as measured by the EQ-i-influence transformational leadership and/or desirable outcomes? Leadership \& Organization Development Journal, 27, 330351.

- Delphine Nelis, Jordi Quoidbach, Moïra Mikolajczak and Michel Hansenne (2009). Increasing emotional intelligence: (How) is it possible? Original Research Article Personality and Individual Differences, Volume 47, Issue 1, July 2009, Pages 36-41

- Diane Perrons (2003). The New Economy and the Work-Life Balance: Conceptual Explorations and a Case Study of New Media, Volume 10, Issue 1, pages 65-93

- Ferrer, $A$ \& Gagne, L. (2006). The use of family friendly work place practices in Canada. Institute for Research on Public Policy Working Paper Series no. 2006-02.

- Gambles, R, Lewis, $S$ \& Rapoport (2006), The Myth of Work - Life Balance, John Wiley and Sons

- Goleman, D. (1998). Working with emotional intelligence. New York: Bantam Books

- Grover, S.L \& Crooker, K.J. (1995). Who appreciates family - responsive human resource policies, The impact of family friendly policies on the organisational attachment of parents and non - parents, Personnel Psychology, 48, 271-288.

- Holahan, C.K. and Sears, R.R. (1995). The gifted group in later maturity. Stanford: Stanford University Press

- Hopkins, M. M, Bilimoria, D. (2008). Social and Emotional Competencies Predicting Success for Male and Female Executives (1 ed., vol. 27, pp. 13-35). Journal of Management Development.
- MacCann, C., Matthews, G., Zeidner, M., \& Roberts, R. D. (2003). Psychological assessment of emotional intelligence: $A$ review of self-report and performance-based testing. The International Journal of Organizationa Analysis, 11(3), 247-274.

- McCrae, R. R. (2000). Emotional intelligence from the perspective of the fivefactor model of personality. In R. Bar-On \& J. D. A. Parker (Eds.), Handbook of emotional intelligence (pp. 263-276). San Francisco: Jossey-Bass.

- McClelland, D. C. (1975). A competency model for human resource management specialists to be used in the delivery of the human resource management cycle.

- Thomas, L.T\& Ganster, D.C (1995). "Impact of family - supportive work variables on work - family conflict and strain: A control perspective". Journal of Applied Psychology. Washington. Vol. 108, Iss. 1 pg 6, lopgs.

- Thomas, L.T.\& Ganster, D.C (1995). "Impact of family - supportive work variables on work - family conflict and strain: A control perspective". Journal of Applied Psychology, 80, 6-15.

- Vakola, M. Tsaousis, I., \& Nikolaou, I. (2003). The role of emotional intelligence and personality variables on attitudes toward organizational change. Journal of Managerial Psychology, 19, 88-110.

- Williams, (1994). Leadership for the 21st Century: Life Insurance Leadership Study. Boston: HayGroup.

- Zimmerman, T.S (2003). Intimate partnership: Foundation to the successful balance of family and work. The American Journal of family Tehrapy, Volume 31, Issue 2 , pages $107-124$. 